\title{
Erythropoietic Porphyria
}

National Cancer Institute

\section{Source}

National Cancer Institute. Erythropoietic Porphyria. NCI Thesaurus. Code C84697.

A rare congenital metabolic disorder characterized by an inborn error of porphyrin-heme biosynthesis. It is caused by deficiency of the enzyme uroporphyrinogen III cosynthetase. It results in cutaneous photosensitivity leading to blistering and scarring of the exposed skin areas. 